\title{
Effect of sweeteners on the quality characteristics of ginger (Zingiber officinale Rosc) Jungkwa
}

\author{
Yeong-Min Lee ${ }^{1}$, Hyeon-Jeong Lee ${ }^{1}$, Jeong-Seok Cho ${ }^{1,2}$, Ji-Young Choi ${ }^{1}$, \\ Jin-Ho Woo ${ }^{1}$, Kwang-Deog Moon ${ }^{1,2 *}$ \\ ${ }^{1}$ School of Food Science and Biotechnology, Kyungpook National University Daegu 41566, Korea \\ ${ }^{2}$ Food and Bio-Industry Research Institute, Kyungpook National University, Daegu 41566, Korea
}

\section{감미료가 생강정과의 품질특성에 미치는 영향}

\author{
이영민 ${ }^{1} \cdot$ 이현정 $^{1} \cdot$ 조정석 ${ }^{1,2} \cdot$ 최지영 ${ }^{1} \cdot$ 우진호 $^{1} \cdot$ 문광덕 $^{1,2 *}$ \\ ${ }^{1}$ 경북대학교 식품공학부 식품생물공학전공, ${ }^{2}$ 식품생물산업연구소
}

\begin{abstract}
In this study the physicochemical properties and antioxidant capacities of ginger (Zingiber officinale Rosc) Jungkwa with different kinds of sweeteners were determined. Jungkwa made with different sugars (sugar, xylitol, honey or oligosaccharides) were compared in aspect of physiochemical properties, antioxidant activities, total phenolic contents and sensory evaluation. Moisture contents Jungkwa treated different kinds of oligosaccarides showed highest value, in the order of honey, xylitol and sugar. $\mathrm{L}^{*}$ value of Jungkwa treated with xylitol was the highest, $\mathbf{a}^{*}$ value of Jungkwa treated with honey, sugar JungKwa were higher then others. Free sugar contents of Jungkwa treated with sugar showed the highest value in sucrose, glucose and galactose. Jungkwa with xylitol showed lowest value in all free sugar contents. Hardness and chewiness of Jungkwa treated with xylitol showed the highest value. The antioxidant activity measured by DPPH and ABTS radical scavenging activity and total penolic content were the highest in Jungkwa treated with honey, followed by Jungkwa treated with xylitol, oligosaccharides and sugar. Appearance and color of oligosaccarides and honey treated Jungkwa were preferred. In ginger taste, sweetness, chewiness were highest in sugar treated Jungkwa (not significant difference in treatments). As a result, honey treated Jungkwa has higher antioxidant activity and quality than other sugar treatments.
\end{abstract}

Key words : ginger, Jungkwa, sweeteners, physicochemical properties, antioxidant capacities

\section{서 론}

생강(Zingiber officinale Rosc)은 생강과에 속하는 아열대, 또는 열대 원산의 다년생 초본 식물의 하나이다. 생생강 (fresh ginger), 건생강(dried ginger), 정유 등의 형태로 유통 되며 식용, 약용 또는 화장품용으로 널리 사용되고 있다 $(1,2)$. 생강에 관한 선행 연구로는 재배지에 따른 성분비교

*Corresponding author. E-mail : kdmoon@knu.ac.kr Phone : 82-53-950-5773, Fax : 82-53-950-6772

Received 6 December 2016; Revised 10 May 2017; Accepted 19 June 2017.

Copyright (c) The Korean Society of Food Preservation. All rights reserved.
(3) 및 아미노산조성(4) 등의 연구결과가 보고되어있으며 생강의 flavor와 밀접한 관계가 있는 매운맛 성분(5)과 방향 성분(6)에 관해서도 연구가 수행되어져 왔다. 생강은 주로 10-11월에 수확하여 저장 한 후 연중 유통되나 $10^{\circ} \mathrm{C}$ 이하에 서는 저온장해가 발생하고 $18^{\circ} \mathrm{C}$ 이상에서는 발아(7) 및 곰 팡이 번식과 표면건조 및 연화 등으로 인하여 저장성이 매우 낮은 편이다(8). 생강 저장의 어려움을 해결하고 소비 형태의 다양성을 증가시키기 위해 생강가루를 첨가한 찹쌀 머핀(9), 생강 가루를 이용한 생강잼(10) 등의 연구가 진행 되었다.

정과는 식물의 뿌리나 줄기 등을 졸여서 달고 쫄깃한 형태가 되도록 하는 것으로 연근, 생강, 당근, 도라지 등을 이용한 정과가 있다(11). 최근 당노, 성인병 및 비만식품의 
증가로 자연식품에 대한 관심이 증가하고 있는데 이에 과일 과 채소를 이용한 정과가 다시 선호되고 있다(12). 정과에 사용되는 감미료는 설탕, 포도당, 과당, 꿀, 올리고당과 같 은 천연 감미료와 스테비오사이드, 사카린 등과 같은 인공 감미료가 있다. 이러한 대체 감미료는 설탕과 유사한 단맛 을 지니면서 열량이 전혀 없거나, 설탕에 비해 현저하게 낮은 칼로리로 체중 감소에 도움이 되고 충치와 당뇨병을 예방하는데 도움이 된다(13). 정과와 관련된 연구로 감미료 의 종류를 달리한 수삼정과의 품질특성(14), 당 종류를 달리 하여 제조한 지황정과의 품질특성 및 항산화성(15) 등이 있다.

생강의 저장성 향상이나 생강을 첨가한 가공품에 대해서 는 여러 연구가 진행되어 왔지만 생강의 가공과정에서 변화 하는 이화학적 특성이나 기능성 성분, 생강 자체로 만든 가공품에 대한 연구는 부족한 실정이다. 따라서 본 연구에 서는 다양한 생리활성 기능을 가진 생강으로 당 종류를 달리하여 정과를 제조하였을 때 품질 특성을 조사하여 기능 성이 높은 생강 가공품을 제조하고자 한다.

\section{재료 및 방법}

\section{실험 재료}

본 실험에 사용한 원료 생강은 2015년 11월 충청남도 서산에서 생산된 생강 중 흠이 없고 크기나 색깔이 비슷한 품질이 좋은 상품을 선정하여 사용하였으며 정과 제조에는 백설탕(100\% 원당, CJ, Incheon, Korea), 자일리톨(100\% xylitol, Roquette, Lestrem, France), 꿀(사양벌 꿀 $90 \%$, 잡화 꿀 $10 \%$, 고려인삼주식회사, Gangwon, Korea), 건강한 올리 고당(프락토 올리고당 50\% 이상, CJ, Incheon, Korea)을 사 용하였다.

\section{정과의 제조}

생강은 크기와 형태가 균일한 것을 선별하고 절단기 (RG-100, Hallde, Sweden)를 이용하여 $0.4 \mathrm{~cm}$ 두께로 일정 하게 절단하였으며 예비 실험을 통해 기능성 성분의 유출이 가장 적은 $80^{\circ} \mathrm{C}$ 의 열수에서 한 시간 동안 증숙한 생강편을 사용하였다. 열수 처리된 생강은 물기를 제거하고 설탕, 자일리톨, 꿀, 올리고당을 생강과 $2: 1(\mathrm{w} / \mathrm{w})$ 의 비율로 섞어 예비실험을 거쳐 약 $80^{\circ} \mathrm{C}$ 에서 40 분간 졸여 제조하였다.

\section{수분함량 측정}

정과의 수분함량은 각 시료 $2 \mathrm{~g}$ 을 취하여 적외선 수분 측정기(FD-720, Kett Electric Laboratory Co., Ltd., Tokyo, Japan)를 사용하여 측정하였으며 시료는 3 회 반복 측정하 여 그 평균값을 구하였다.

\section{$\mathrm{pH}$ 및 가용성 고형분 함량 측정}

생강편의 $\mathrm{pH}$ 는 시료에 4 배에 해당하는 증류수와 희석 및 마쇄 후, 서서히 교반하면서 $\mathrm{pH}$ meter(Orion 3 star, Thermo Electron Co., Waltham, MA, USA)를 사용하여 측정 하였다. 증류수에 의한 희석배수는 측정된 $\mathrm{pH}$ 값에 별도로 반영하지 않았다.

가용성 고형분 함량은 시료 $10 \mathrm{~g}$ 에 증류수 $40 \mathrm{~mL}$ 를 첨가 하고 homogenizer(AM-9, Nihonseiki Kashima Co., Ltd., Tokyo, Japan)를 이용하여 마쇄한 후 검액을 굴절당도계 (Master-a, ATAGO Co., Tokyo, Japan)로 측정하여 ${ }^{\circ}$ Brix로 나타내었으며, 희석배수는 측정된 값에 별도 반영하지 않 았다.

\section{색도 측정}

색도는 표준 백색판 $\left(\mathrm{L}^{*}=97.79, \mathrm{a}^{*}=-0.38, \mathrm{~b}^{*}=2.05\right)$ 으로 보 정된 colorimeter(CR-400, Minolta Co., Osaka, Japan)를 사용 하였다. 처리구 당 시료 10 개를 임의로 선택하여 표면의 색차를 각각 3 회 반복 측정한 후 평균값을 이용하였다. $\mathrm{L}^{*}$ 은 lightness, $a^{*}$ 는 redness, $b^{*}$ 는 yellowness를 나타낸 값이다.

\section{물성 측정}

생강 정과의 물성은 rheometer(Compac-100П, SunScientific Co., Tokyo, Japan)를 이용하여 측정하였다. $5 \mathrm{~mm}$ cylinder probe를 사용하여 견고성(hardness), 탄력성(springiness), 응 집성(cohesiveness), 씹힘성(chewiness)을 시료별로 15회 측 정 후 평균값을 이용하였다. 조건은 sample height $4 \mathrm{~mm}$, sample width $40 \mathrm{~mm}$, adaptor type cycle, table speed 60 $\mathrm{mm} / \mathrm{min}$ 로 설정하였으며 penetration distance는 sample height의 $40 \%$ 로 설정하여 $1.6 \mathrm{~mm}$ 침투되도록 하였다.

\section{유리당 함량 측정}

열수처리된 생강의 유리당 함량을 분석하기 위해 정과 $5 \mathrm{~g}$ 에 증류수 $45 \mathrm{~mL}$ 를 가하여 3 시간 동안 $50^{\circ} \mathrm{C}$ 온수에서 초음파 추출을 하였으며 추출물을 Whatman No. 4로 여과 한 후, $0.45 \mu \mathrm{m}$ membrane filter로 여과하여 HPLC (Prominence, Shimadzu Co., Tokyo, Japan)를 실시하였다 (column: Sugar- Pak I column(Waters Co.) $\varnothing 6.5 \times 300 \mathrm{~mm}$, column, temp: $90^{\circ} \mathrm{C}$, mobile phase: 0.01M Ca-EDTA buffer $\left(50 \mathrm{mg} / \mathrm{L} \mathrm{Ld} . \mathrm{H}_{2} \mathrm{O}\right)$, flow late: $0.5 \mathrm{~mL} / \mathrm{min}$, sample injection vol: $20 \mu \mathrm{L}$, detector: RI model RID-10A). 표준품은 glucose(Duksan Science, Seoul, Korea), fructose(Daejung Chemicals \& Metals Co., Siheung, Korea), sucrose(Sigma Chemical Co., St. Louis, MO, USA), galactose(Samchun Chemical, Cheonan, Korea)를 일정량씩 혼합하여 증류수에 녹여 표준용액으로 사용하였다. 표준품과 시료의 당 성분 은 머무른 시간을 비교하여 확인하였고 peak의 면적으로 각각의 당 함량을 산출하였다. 


\section{항산화 활성 측정}

DPPH radical assay는 Blois의 방법(16)을 변용하여 측정 하였다. 시료용액 제조는 정과 $5 \mathrm{~g}$ 을 $80 \%$ ethanol $45 \mathrm{~mL}$ 을 가하여 10 배 희석된 시료를 증류수로 채운 초음파발생기 (40 kHz, Daihan Scientific Co., Ltd., Seoul, Korea)를 이용하 여 상온에서 30 분동안 초음파 추출하였다. 이 시료원액을 희석하지 않고 실험에 그대로 이용하였다. $0.4 \mathrm{mM} \mathrm{DPPH}$ 용액을 흡광도 값이 0.95-0.99가 되도록 ethanol로 보정한 후 시료용액과 $4: 1$ 로 혼합하고 10 초간 진탕하고 10 분간 암소에서 정치한 후 반응한 용액을 UV-visible spectrophotometer (Evolution 201, Thermo Fisher Scientific Inc, Madison, WI, USA)를 사용하여 $517 \mathrm{~nm}$ 에서 흡광도를 측정하였으며 다 음 식에 의하여 DPPH 라디칼 소거능을 나타내었다.

DPPH radical scavenging activity $(\%)=\frac{\text { blank absorbance-sample absorbance }}{\text { blank absorbance }} \times 100$

$\mathrm{ABTS}$ 라디칼 소거능 측정은 $\mathrm{Re}$ 등의 방법(17)을 변용하 여 측정하였다. 추출액은 DPPH radical assay에 사용된 시료 와 동일한 방법으로 제조하였다. $7.4 \mathrm{mM} \mathrm{ABTS}$ 에 $2.45 \mathrm{mM}$ potassium persulphate를 1:1로 섞은 후, 암소에 14시간 동안 방치하여 양이온 라디칼(ABTS-)을 형성시킨 후, $734 \mathrm{~nm}$ 에서 흡광도의 값이 1.00 이하가 되도록 희석하였다. 희석 된 $\mathrm{ABTS}+{ }^{+}$용액 $980 \mu \mathrm{L}$ 에 시료용액 $20 \mu \mathrm{L}$ 를 가한 뒤 10 분간 정치한 후 흡광도를 측정하였으며 다음 식에 의하여 ABTS 라디칼 소거능을 나타내었다.

ABTS radical scavenging activity $(\%)=\frac{\text { blank absorbance-sample absorbance }}{\text { blank absorbance }} \times 100$

\section{총 페놀성 화합물 함량 측정}

총 페놀성 화합물 함량(total phenolic content, TPC)은 Folin-Ciocalteu 법(13)을 응용하여 정량하였다. 시료는 정 과 $5 \mathrm{~g}$ 을 $80 \%$ ethanol $45 \mathrm{~mL}$ 로 30 분간 초음파 추출한 것을 사용하였고, 이 시료원액을 희석하지 않고 실험에 그대로 이용하였다. 시료액 $1 \mathrm{~mL}$ 에 Folin-Ciocalteu reagent $1 \mathrm{~mL}$ 를 혼합하여 15 분간 정치한 후 $10 \% \mathrm{Na}_{2} \mathrm{CO}_{3} 1 \mathrm{~mL}$ 를 첨가하여 60 분 동안 암소에서 반응시켜 UV-visible spectrophotometer (Evolution 201, Thermo Fisher Scientific Inc., USA)로 700 $\mathrm{nm}$ 에서 흡광도를 측정하였으며, tannic acid를 표준물질로 하여 총 페놀성 화합물의 함량을 tannic acid equivalent (TAE) $\mathrm{mg} / \mathrm{kg}$ 으로 나타내었다.

\section{관능검사}

관능검사는 실험에 대한 검사방법에 충분히 훈련된 15 명 의 경북대학교 식품공학부 대학원생들을 대상으로 실시하 였다. 평가 항목은 색(color), 외관(appearance), 향(flavor), 맛(taste), 생강맛(ginger taste), 단맛(sweet taste), 씹힘성 (chewiness), 전반적 기호도(overall preference)를 검사하였 고, 7점 척도법(1점, 매우 나쁘다; 7점, 매우 좋다)으로 표시 하도록 하였다.

\section{통계처리}

모든 실험 결과는 3회 반복하여 실시하였고 그 결과 값을 평균과 표준편차로 표시하고(mean $\pm \mathrm{SD}), \mathrm{SAS}$ program(9.4, SAS Institute, Inc., Cary, NC, USA)을 이용하여 분산분석과 Duncan's multiple range test $(\mathrm{p}<0.05)$ 를 실시하였다.

\section{결과 및 고찰}

\section{수분함량, $\mathrm{pH}$ 및 가용성 고형분 함량}

감미료를 달리하여 제조한 생강정과의 수분함량, $\mathrm{pH}$, 가 용성 고형분 함량을 Table 1 에 나타내었다. 정과의 수분함 량은 설탕 $19.63 \%$, 자일리톨 $20.54 \%$, 꿀 $32.14 \%$, 올리고당 $33.25 \%$ 로 시료 간에 유의적인 차이를 나타내었으며 프락토 올리고당의 경우, 설탕의 과당 잔기에 과당 분자를 1-3개 정도 $\beta$ 결합시킨 것으로 보습성이 클것으로 보인다(16). 또 한 가용성 고형분 함량은 자일리톨이 $7.07{ }^{\circ} \mathrm{Brix}$ 로 가장 높은 수치를 나타내었다. 감미료 각각의 특색이 다르기 때 문에 장시간 뜨거운 액체로 졸여질 경우 결정의 모양과 형태, 수분흡수력 등이 달라서 수분함량과 가용성 고형분 함량에 차이가 나는 것으로 생각된다. 설탕과 자일리톨 처 리구는 수분함량이 적어 표면에 결정이 생성된 반면 꿀과 올리고당 처리구는 완전히 건조되지 않고 끈적이는 제형을 나타내었다. 정과의 $\mathrm{pH}$ 는 올리고당이 5.82로 가장 낮았으 며 설탕이 6.59로 가장 높은 값을 나타내었다.

Table 1. Moisture contents, $\mathrm{pH}$ and soluble solid content of ginger Jungkwa treated with different types of sweeteners

\begin{tabular}{cccc}
\hline Samples & Moisture contents (\%) & $\begin{array}{c}\text { Total soluble solid contents } \\
\left({ }^{\circ} \text { Brix }\right)\end{array}$ & $\mathrm{pH}$ \\
\hline Sugar & $19.63 \pm 0.52^{\mathrm{d} 1)}$ & $6.37 \pm 0.06^{\mathrm{b}}$ & $6.59 \pm 0.08^{\mathrm{a}}$ \\
Xylitol & $20.54 \pm 0.49^{\mathrm{c}}$ & $7.07 \pm 0.15^{\mathrm{a}}$ & $6.48 \pm 0.02^{\mathrm{ab}}$ \\
Honey & $32.14 \pm 0.13^{\mathrm{b}}$ & $5.70 \pm 0.30^{\mathrm{c}}$ & $6.02 \pm 0.09^{\mathrm{c}}$ \\
Oligosaccharides & $33.25 \pm 0.08^{\mathrm{a}}$ & $5.97 \pm 0.06^{\mathrm{c}}$ & $5.82 \pm 0.09^{\mathrm{d}}$ \\
\hline
\end{tabular}

${ }^{10}$ Means \pm SD ( $\mathrm{n}=3$ ) with different letters in the same column represent significantly different at $5 \%$ level.

\section{색도 및 물성}

감미료를 달리하여 제조한 생강정과의 $\mathrm{L}^{*}, \mathrm{a}^{*}, \mathrm{~b}^{*}$ 값을 Table 2에 나타내었다. $\mathrm{L}^{*}$ 값의 경우 자일리톨로 제조한 정과가 $60.48 \pm 7.94$ 로 가장 높았으며 나머지 처리구는 유의 적인 차이가 없었다. 이는 자일리톨 정과의 표면에 형성된 결정이 정과의 명도에 영향을 미친 것으로 생각된다. 설탕 
정과에서도 결정이 형성되었으나 결정의 크기가 크고 부분 적으로 분포하여 전반적인 색차에는 영향을 미치지 않은 것으로 생각된다. 이는 최종적으로 제품이 완료되었을 때 당도가 매우 높아 과포화 의해 생기는 석출현상이 감미료 종류에 따라 다르게 일어남으로 이는 색도에 영향을 미칠 수 있음을 보여준다. $\mathrm{a}^{*}$ 값의 경우에는 꿀로 만든 정과가 1.02 로 가장 높은 값을 나타내었고 설탕, 자일리톨, 올리고 당 순으로 나타났다. 감미료를 달리하여 제조한 생강정과 의 물성은 Table 3에 나타내었다. 이는 설탕으로 제조한 수삼정과의 황색도와 적색도가 자일리톨로 제조한 수삼정 과의 황색도가 유의적으로 낮았다는 Jo 등(14)의 결과와 유사하였다. 정과의 물성은 제조에 사용되는 당에 따라 물 성학적 특성이 다르게 나타나는데(17) 경도의 경우 자일리 톨로 제조한 정과가 $75,330 \pm 9,863 \mathrm{~g} / \mathrm{cm}^{2}$ 으로 가장 높은 값 을 나타내었고 설탕, 꿀, 올리고당 처리구의 경우 유의적인 차이를 보이지 않았다. 씹힘성은 경도에 비례하는 경향을 보이는데 생강정과의 경우에도 경도와 씹힘성이 유사한 경향을 나타내었다. 탄력성에서 xylitol 처리구는 꿀 또는 올리고당 처리구와 유의적인 차이가 있으며, 응집성의 경 우에는 설탕 처리구와 xylitol 처리구에서 유의적인 차이를 보였다. 또한 올리고당으로 제조한 생강정과의 씹힘성이 가장 낮다는 결과는 Jo 등(14)이 연구한 수삼정과에 대한 결과와 일치하였다.

Table 2. Color values of ginger Jungkwa treated with different types of sweeteners

\begin{tabular}{cccc}
\hline Samples & $\mathrm{L}^{*}$ & $\mathrm{a}^{*}$ & $\mathrm{~b}^{*}$ \\
\hline Sugar & $44.98 \pm 2.91^{\mathrm{bl})}$ & $0.79 \pm 1.07^{\mathrm{b}}$ & $20.97 \pm 3.21^{\mathrm{c}}$ \\
Xylitol & $60.48 \pm 7.94^{\mathrm{a}}$ & $-0.05 \pm 0.70^{\mathrm{c}}$ & $21.55 \pm 2.74^{\mathrm{bc}}$ \\
Honey & $40.78 \pm 2.26^{\mathrm{c}}$ & $1.02 \pm 0.89^{\mathrm{a}}$ & $22.50 \pm 2.56^{\mathrm{ab}}$ \\
Oligosaccharides & $42.44 \pm 2.48^{\mathrm{c}}$ & $-0.62 \pm 0.94^{\mathrm{d}}$ & $23.46 \pm 2.33^{\mathrm{a}}$ \\
\hline
\end{tabular}

${ }^{1)}$ Means \pm SD ( $n=3$ ) with different letters in the same column represent significantly different at $5 \%$ level.
를 이용하여 생강의 fructose, glucose와 sucrose함량이 0.23 , $0.20,0.44 \%$ 검출되었다고 보고하였다. 하지만 이와는 달리 Choi 등(20)의 연구에서는 sucrose이 매우 미량이며, glucose 와 fructose가 대부분이고 저장, 살균과정 그리고 발효과정 에서 이들이 sucrose로 전환된다고 보고하였습니다. 따라서 생강의 유리당 함량과 그 조성은 원료 품종이나, 재배지에 따라 다를수 있으며, 유통과정에서도 변화가 있으며, 특히

Table 4. Free sugar contents of ginger Jungkwa treated with different types of sweeteners

\begin{tabular}{ccccc} 
& & & & $(\mathrm{mg} / \mathrm{g})$ \\
\hline Samples & Sucrose & Glucose & Fructose & Galactose \\
\hline Sugar & $84.67 \pm 1.52^{\mathrm{a} 1)}$ & $389.13 \pm 6.09^{\mathrm{a}}$ & $\mathrm{ND}^{2}$ & $272.49 \pm 3.70^{\mathrm{a}}$ \\
Xylitol & $0.13 \pm 0.00^{\mathrm{d}}$ & $0.26 \pm 0.02^{\mathrm{d}}$ & $0.14 \pm 0.01^{\mathrm{b}}$ & $\mathrm{ND}$ \\
Honey & $37.73 \pm 1.65^{\mathrm{b}}$ & $219.8 \pm 7.63^{\mathrm{c}}$ & $246.82 \pm 8.31^{\mathrm{a}}$ & $\mathrm{ND}$ \\
Oligosaccharides & $25.22 \pm 0.54^{\mathrm{c}}$ & $264.68 \pm 4.62^{\mathrm{b}}$ & $\mathrm{ND}$ & $134.60 \pm 2.05^{\mathrm{b}}$ \\
\hline
\end{tabular}

${ }^{1)}$ Means \pm SD ( $\mathrm{n}=3$ ) with different letters in the same column represent significantly different at $5 \%$ level.

${ }^{2)} \mathrm{ND}$, Not detected.

고온으로 졸이는 정과 가공과정에서는 더욱 큰 변화가 있을 것으로 보인다. 설탕으로 제조한 정과에서 sucrose, glucose 함량이 처리구 중 가장 높게 나타내었으며 fructose는 검출 되지 않았다. 이는 설탕으로 제조한 인삼 정과의 유리당 분석 결과 fructose의 함량이 비교적 높게 나타났다는 Lee 등(21)의 결과와 일치하지 않았다. Choi 등(20)의 연구의 살균 및 저장 중 fructose가 glucose보다 급격히 감소한다는 결과에서 보듯이 고온 장시간의 가공 과정에서 glucose보다 구조적 변화가 쉬운 특성으로 보다 급격히 변화한 것으로 보인다. 자일리톨 처리구의 경우 당 성분이 sucrose는 0.13 $\mathrm{mg} / \mathrm{g}$, glucose는 $0.26 \mathrm{mg} / \mathrm{g}$ 으로 극히 미량이었고, fructose는 검출되지 않았다. 꿀 처리구는 fructose함량이 $246.82 \mathrm{mg} / \mathrm{g}$ 으 로 가장 높았으며 glucose, sucrose가 역시 적지 않은 양이

Table 3. Texture properties of ginger Jungkwa treated with different types of sweeteners

\begin{tabular}{ccccc}
\hline Samples & $\begin{array}{c}\text { Hardness } \\
\left(\mathrm{g} / \mathrm{cm}^{2}\right)\end{array}$ & $\begin{array}{c}\text { Springiness } \\
(\mathrm{g})\end{array}$ & $\begin{array}{c}\text { Cohesiveness } \\
(\mathrm{g})\end{array}$ & $\begin{array}{c}\text { Chewiness } \\
(\mathrm{g})\end{array}$ \\
\hline Sugar & $25,340 \pm 9,348^{\mathrm{bl}}$ & $101.67 \pm 0.99^{\mathrm{ab}}$ & $158.14 \pm 28.29^{\mathrm{a}}$ & $3,207 \pm 1,479^{\mathrm{b}}$ \\
Xylitol & $75,330 \pm 9,863^{\mathrm{a}}$ & $98.01 \pm 10.44^{\mathrm{b}}$ & $133.98 \pm 27.67^{\mathrm{b}}$ & $7,675 \pm 2,079^{\mathrm{a}}$ \\
Honey & $29,370 \pm 8,613^{\mathrm{b}}$ & $102.52 \pm 2.73^{\mathrm{a}}$ & $144.55 \pm 22.57^{\mathrm{ab}}$ & $3,279 \pm 1,138^{\mathrm{b}}$ \\
Oligosaccharides & $24,780 \pm 7,397^{\mathrm{b}}$ & $103.94 \pm 1.47^{\mathrm{a}}$ & $150.33 \pm 26.56^{\mathrm{ab}}$ & $2,805 \pm 779^{\mathrm{b}}$ \\
\hline
\end{tabular}

${ }^{1)}$ Means \pm SD ( $\mathrm{n}=15$ ) with different letters are significantly different at $5 \%$ level.

\section{유리당 함량}

감미료를 달리하여 제조한 생강정과의 유리당 함량은 Table 4에 나타내었다. 생강원료의 유리당 조성에 대한 연 구는 Lee 등(18)에 의해 보고 되었으며, Kim 등(19)은 HPLC
검출되었다. 꿀처리구가 xylitol처리구보다 훨씬 많은 유리 당을 함유함에도 불구하고 가용성 고형분이 xylitol처리구 보다 낮게 나온 것은 꿀이 보수력을 가지고 있기 때문에 수분함량이 높아 당성분이 희석되었을 것으로 보인다. 올 
리고당 처리구의 경우 glucose함량이 가장 높았으며 fructose는 검출되지 않았다. 실험에 사용된 프락토올리고 당은 포도당, 과당등의 단당류가 glycoside 결합에 의해 탈 수 축합된 중합도 2-10의 소당류에 대한 총칭이며, 구성 당 종류에 따라 다양하다(20). 이러한 올리고당은 쉽게 분해 되지 않아 에너지원으로 이용되지 않는 저칼로리 감미료이 며, 감미도 역시 설탕의 30-50\%로 낮다(23). 특히 난소화성 올리고당인 프락토올리고당은 분해 되지 않고 대장까지 도달하여, 식이섬유와 같은 다양한 기능을 가진 것으로 알 려져있다(24). 따라서 분해나 다른 물질로의 전이가 어려우 므로 fructose가 증가하지 않은 것으로 사료된다. galactose 가 증가한 이유에 대해서는 추후 좀 더 면밀한 검토로 고찰 되어야 할 것으로 보인다. 이와 같이 정과 제조시 사용되는 당의 종류에 따라 최종 정과제품의 구성 당에 큰 영향을 미치게 되므로 정과 제조 시 적절한 당 종류를 선택할 필요 가 있을 것으로 생각된다.

\section{항산화 활성 및 페놀화합물 함량}

감미료를 달리하여 제조한 생강정과의 DPPH 라디칼 소 거능은 Fig. 1에 제시하였다. 라디칼 소거능에 사용된 DPPH 는 안정한 자유라디칼로 $517 \mathrm{~nm}$ 부근에서 최대 흡광도를 나타내며 전자 또는 수소를 받으면 $517 \mathrm{~nm}$ 부근에서 흡광 도가 감소하고(25), 방향족 아민류 및 방향족 화합물 등에 의해 환원되어 짙은 보라색이 탈색되는 것으로 항산화능을 측정하는 방법이다(26). 꿀을 이용하여 제조한 정과의 라디 칼 소거능이 $60.11 \%$ 로 가장 높게 나타났으며 자일리톨, 올리고당, 설탕 순으로 나타났다. 이는 벌꿀에는 플라보노 이드, 페놀 화합물, 각종 효소, 비타민 $\mathrm{C}$, 유기산, 아미노산 등 항산화 활성과 관련된 물질이 많아 항산화 활성이 높게 나타난다는 Kim 등(27)의 보고와 유사하였다. 생강정과의 ABTS 라디칼 소거능은 Fig. 2에 제시하였다. 꿀로 제조한

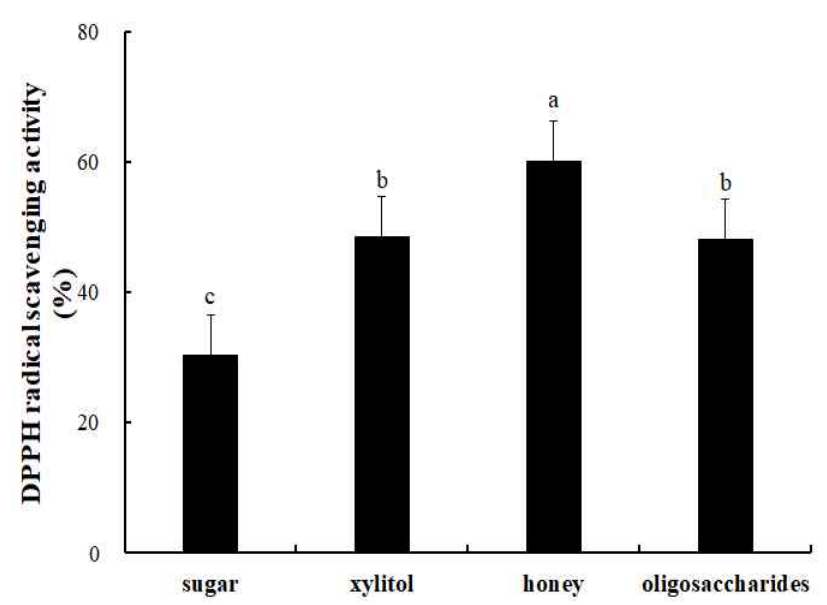

Fig. 1. DPPH radical scavenging activity of ginger Jungkwa treated with different type of sweeterners.

Means $\pm \mathrm{SD}$ ( $\mathrm{n}=3$ ) with different letters in the same column represent significantly different at $5 \%$ level.
생강정과의 $\mathrm{ABTS}$ 라디칼 소거능이 $62.79 \%$ 로 가장 높게 나타났으며 설탕으로 제조한 정과가 $37.57 \%$ 로 가장 낮은 값을 보였다. 이는 앞서 진행한 DPPH 라디칼 소거능 실험 결과와 유사한 경향을 나타내었다. 감미료를 달리하여 제 조한 생강정과의 총 페놀성 화합물 함량은 Fig. 3과 같으며 $\mathrm{mg}$ tannic acid equivalent(TAE) $/ \mathrm{kg}$ 로 나타내었다. 꿀을 이 용하여 제조한 생강정과의 경우 총 페놀성 화합물의 함량이 가장 높았으며 자일리톨, 올리고당, 설탕 순으로 나타났다. 이는 당의 종류를 달리하여 제조한 지황정과의 항산화성을 분석한 Kim 등(15)의 연구에서 total phenol 함량이 꿀, 이소 말토올리고당, 설탕, 솔비톨 순으로 나타난 결과와 유사하 였다.

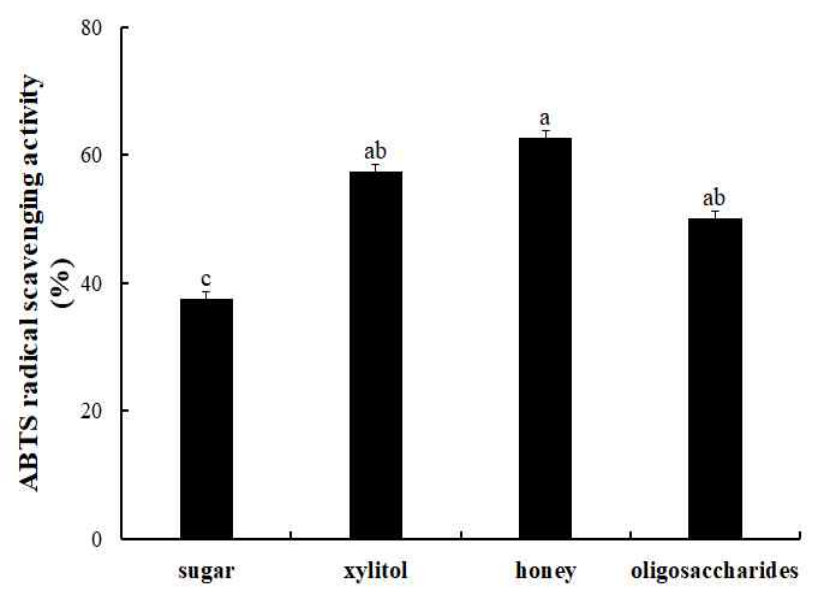

Fig. 2. ABTS radical scavenging activity of ginger Jungkwa treated with different type of sweeterners.

Means $\pm \mathrm{SD}(\mathrm{n}=3)$ with different letters in the same column represent significantly different at $5 \%$ level.

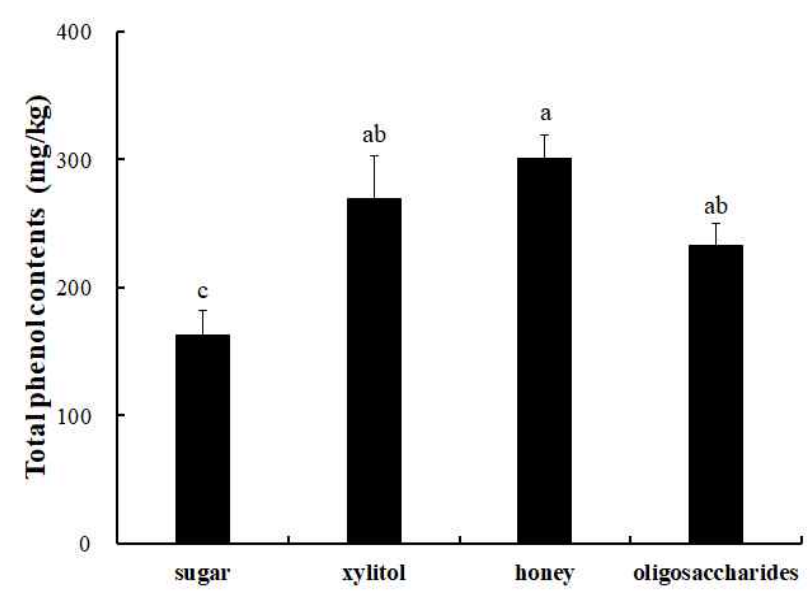

Fig. 3. Total phenol contents of ginger Jungkwa treated with different type of sweeterners.

Means $\pm \mathrm{SD}$ ( $\mathrm{n}=3$ ) with different letters in the same column represent significantly different at $5 \%$ level. 
Table 5. Sensory evaluation of ginger Jungkwa treated with different types of sweeteners

\begin{tabular}{ccccccccc}
\hline Sample & Appearance & Color & Odor & Taste & Ginger taste & Sweet taste & Chewiness & Overall preference \\
\hline Sugar & $4.67 \pm 1.11^{\mathrm{abl})}$ & $4.33 \pm 0.90^{\mathrm{bc}}$ & $4.27 \pm 1.16^{\mathrm{a}}$ & $4.87 \pm 1.25^{\mathrm{a}}$ & $5.33 \pm 1.18^{\mathrm{a}}$ & $4.80 \pm 1.15^{\mathrm{a}}$ & $5.20 \pm 1.47^{\mathrm{a}}$ & $4.73 \pm 1.10^{\mathrm{a}}$ \\
Xylitol & $4.00 \pm 1.65^{\mathrm{b}}$ & $3.73 \pm 0.96^{\mathrm{c}}$ & $4.53 \pm 1.19^{\mathrm{a}}$ & $4.47 \pm 1.36^{\mathrm{a}}$ & $4.93 \pm 1.33^{\mathrm{a}}$ & $4.53 \pm 1.30^{\mathrm{a}}$ & $4.73 \pm 1.03^{\mathrm{a}}$ & $4.47 \pm 1.19^{\mathrm{a}}$ \\
Honey & $5.40 \pm 0.63^{\mathrm{a}}$ & $5.80 \pm 0.68^{\mathrm{a}}$ & $5.27 \pm 1.58^{\mathrm{a}}$ & $4.47 \pm 1.51^{\mathrm{a}}$ & $5.07 \pm 1.33^{\mathrm{a}}$ & $4.40 \pm 1.30^{\mathrm{a}}$ & $4.73 \pm 1.71^{\mathrm{a}}$ & $4.93 \pm 1.33^{\mathrm{a}}$ \\
Oligosaccharides & $5.13 \pm 1.19^{\mathrm{a}}$ & $4.87 \pm 0.99^{\mathrm{b}}$ & $4.87 \pm 1.13^{\mathrm{a}}$ & $4.40 \pm 1.24^{\mathrm{a}}$ & $5.00 \pm 1.25^{\mathrm{a}}$ & $4.40 \pm 1.12^{\mathrm{a}}$ & $4.47 \pm 1.06^{\mathrm{a}}$ & $4.73 \pm 1.16^{\mathrm{a}}$ \\
\hline
\end{tabular}

${ }^{1)}$ Means \pm SD ( $n=3$ ) with different letters in the same column represent significantly different at $5 \%$ level.

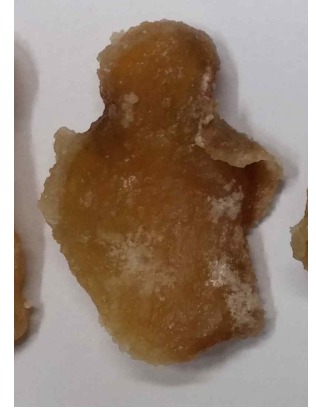

Sugar

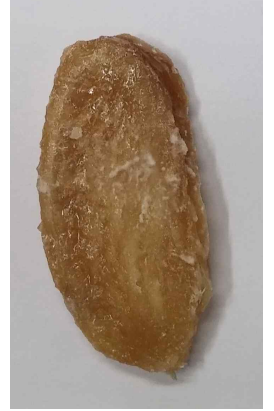

Xylitol

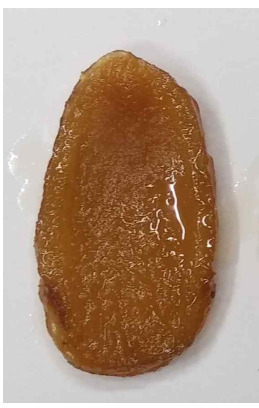

Honey

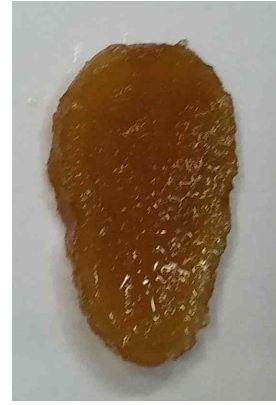

Oligosaccharides

Fig. 4. Photographs of ginger Jungkwa treated with different sweeteners.

관능검사

감미료를 달리하여 제조한 생강정과의 관능검사 결과는 Table 5에 나타내었다. Fig. 4에서 보이는 것과 같이 외관과 색의 경우 건조한 상태인 설탕정과와 자일리톨 정과에 비해 수분이 많은 꿀정과와 올리고당 정과의 선호도가 유의적으 로 높게 나타났다. 위의 색도 분석 결과와 비교해 보았을 때 색의 기호도는 $\mathrm{L}^{*}$ 값이 낮을수록 높은 점수를 나타내었 다. 이에 따라 정과가 어두운 색을 나타낼수록 시각적 기호 도가 높아짐을 알수 있었고, 가장 $\mathrm{L}^{*}$ 값이 낮은 꿀 > 올리고 당 > 설탕 > 자일리톨 순으로 색의 기호도 결과가 나타났다. 생강맛과 단맛, 씹힘성을 측정한 항목에서는 설탕으로 제 조한 정과가 가장 높이 평가되었으나 처리구 간의 유의적인 차이는 나타나지 않았다. 따라서 감미료에 따라 생강의 특 유의 맛이나, 향, 식감에는 큰 차이를 주지 않는 것으로 보인다. 종합적 기호도는 꿀, 설탕, 올리고당, 자일리톨 순 으로 높은 점수를 나타났으며 정과의 제형에 따른 유의적인 차이는 나타나지 않았다.

\section{요 약}

감미료의 종류를 달리하여 제조한 생강정과의 품질 특성 및 항산화성을 분석하여 품질이 향상된 생강정과를 제조하 고자 하였다. 열수처리한 생강을 설탕, 자일리톨, 꿀, 올리 고당과 $2: 1$ 의 비율로 약한불에서 졸여 정과를 제조하였다. 생강정과의 수분함량은 꿀과 올리고당 정과가 높았으며 설탕과 자일리톨 정과는 수분함량이 적어 표면에 결정이
생성되었다. 가용성 고형분 함량은 자일리톨이 $7.07{ }^{\circ} \mathrm{Brix}$ 로 가장 높았다. 정과의 $\mathrm{pH}$ 는 올리고당이 5.82 로 가장 낮았 으며 설탕이 6.59로 가장 높은 값을 나타내었다. 자일리톨 로 제조한 정과의 명도가 가장 높았으며 꿀로 만든 정과가 적색도가 1.02 로 가장 높은 값을 나타내었고 설탕, 자일리 톨, 올리고당 순으로 나타났다. 자일리톨 정과의 hardness와 chewiness 값이 가장 높았으며 다른 항목에서는 유의적인 차이가 나타나지 않았다. 유리당 함량은 설탕으로 제조한 정과의 sucrose, glucose, galactose 함량이 가장 높았으며 자일리톨 처리구의 경우 당 성분이 극히 미량이거나 검출되 지 않았다. 꿀로 제조한 생강정과의 $\mathrm{DPPH}, \mathrm{ABTS}$ 라디칼 소거능이 가장 높게 나타났으며 총 페놀성 화합물 함량도 꿀이 가장 높았고 자일리톨, 올리고당, 설탕 순으로 나타났 다. 관능검사에서 꿀과 올리고당으로 제조한 정과가 외관 과 색의 선호도가 유의적으로 높게 나타났으며 종합적 기호 도는 꿀, 설탕, 올리고당, 자일리톨 순으로 나타났다. 이상 의 실험 결과로 미루어 보아 생강정과를 제조할 때 꿀을 사용하는 것이 정과의 품질과 기호도를 높일 수 있을 것으 로 생각된다.

\section{References}

1. Lee YN (1996) Flora of Korea. Kyohaksa, Seoul, Korea, p 1107-1109

2. Lee CB (1979) Illustrated Flora of Korea. Hyangmoon Publish Co, Seoul, Korea, p 231 
3. Chung TY, Jeong MC, Lee SE, Kim DC, Kim OW (1996) Morphological characteristics of ginger depending on habitat. Korean J Food Sci Technol, 28, 834-840

4. Takahashi M, Osawak, Sato T, Ueda J (1982) Components of amino acids of Zinga officinale Roscoe. Ann Rep Tohoku Coll Pharm, 29, 75-88

5. Chen CC (1986) Chromatagraphic analyses of gingerol compounds in ginger (Zingiber Officinale Roscoe) extracted by liquid carbon dioxide. J Chromatogr A, 360, 163-173

6. Moon HI, Lee JH (1997) Volatile aromatic components of ginger (Zingiber Officinale Roscoe) rhizomes and Japanese spice bush (Lindera obtusiloba BL). Korean J Crop Sci, 42, 7-13

7. Enmaya H (1981) Dictionary of food science. Dou Dan Publishing Co, Tokyo, Japan, p 300

8. Jo KS, Kim JH, Shin HS (1996) Major components affecting nonenzymatic browning in ginger (Zingiber officinale Roscoe) paste during storage. Korean J Food Sci Technol, 28, 433-439

9. Lee SM, Joo NM (2011) Characteristics and optimization of processed sweet rice muffin using ginger powder. Korean J Food Cookery Sci, 27, 31-43

10. Park HJ (2009) Quality characteristics of ginger jam with ginger powder. MS Thesis, Chonbuk National University, Korea, p 1-4, p 28-29

11. Blois MS (1958) Antioxidant determinations by the use of a stable free radical. Nature, 181, 1199-1200

12. Re R, Pellegrini N, Proteggente A, Pannala A, Yang M, Rice-Evans C (1999) Antioxidant activity applying and improved ABTS radical cation decolorization assay. Free radic Biol Med, 26, 1231-1237

13. Benvenuti S, Pellati F, Melegari M, Bertelli D (2004) Polyphenols, anthocyanins, ascorbic acid, and radical scavenging activity of Rubus, Ribes, and Aronia. J Food Sci, 69, 164-169

14. Jo EH, Kim HA, Kim YS (2015) Quality characteristics of JungKwa made with ginseng and the effects of different types of sweeteners. Korean J Culinary Res, 21, 248-258

15. Kim HJ, Min SR, Kim MR (2014) Quality characteristics and antioxidant activities of Rehmannia glutinosa JungKwa prepared with different kinds of sugars. Korean J Food Cook Sci, 30, 76-83

16. Spiegel JE, Rose R, Karabell P, Frankos VH, Schmitt DF (1994) Safety and benefits of fructooligosaccharides as food ingredients. Food Technol, 48, 85-89
17. Park MR, Choi SK, Jung IC, Byun GI (2006) Rheological \& sensory characteristics of pine mushroom Jung-Gwa by different amount of saccharide (honey and oligosaccharide). Korean J Food Culture, 21, 695-701

18. Lee SE, Jung MC, Jung TY (1994) A Study on the development of storage facilities for ginger. Korea Food Research Institute Report, E1294-0538

19. Kim JS, Koh MS, Kim YH, Kim MK, Hong JS (1991) Volatile flavor components of Korean ginger (Zingiber officinale Roscoe). Korean J Food Sci Technol, 23, 141-149

20. Choi EJ, Lee KA, Kim BS, Ku KH (2012) Effect of pre-treatment and storage conditions on the quality characteristics of ginger Paste. Prev Nutr Food Sci, 17, 46-52

21. Lee KS, Kim GH, Seong BJ, Kim HH, Song MR, Kim MR, Lee GH (2010) Physicochemical characteristics of ginseng JungKwa produced with hot-water extract from Maegmundong (Liriope platyphylla tubers). J Korean Soc Food Sci Nutr, 39, 1819-1825

22. Park KH (1994) Understand and use food functional ingredients. Inje Food Science Forum collection of treatises, 2, 165-195

23. Heo KT (1995) Physiological functions of oligosaccharides. Food Science and Industry, 28, 24-28

24. Lee MR, Lee KA, Ly SY (2003) Improving effects of fructooligosaccharide and isomaltooligosaccharide contained in sponge cakes on the constipation of female college stutents. J Korean Soc Food Sci Nutr, 32, 621-626

25. Shin YS, Lee JE, Yeon IK, Do HW, Cheung JD, Kang CK, Choi SY, Youn SJ, Cho JG, Kwoen DJ (2008) Antioxidant and antimicrobial effects of extract with water and ethanol of oriental melon (Cucumis melo L.var makuwa Makino). J Korean Soc Appl Biol Chem, 51, 194-199

26. Ancerewicz J, Migliavacca E, Carrupt PA, Testa B, Bree F, Zini R, Tillement JP, Labidalle S, Guyot D, Chauvet-Monges AM, Crevat A, Le Ridant A (1998) Structure-property relationships of trimetazidine derivatives and model compounds as potential antioxidants. Free Radical Biol Med, 25, 113-120

27. Kim HK, Lee MY, Hong IP, Chio YS, Kim NS, Lee ML, Lee SC (2010) Antioxidant an antimicrobial capacity of several monofloral honey correlation with phenolic and flavonoid contents. Korean J Apiculture, 25, 275-282 